\title{
Influence of birth weight on gene regulators of lipid metabolism and utilization in subcutaneous adipose tissue and skeletal muscle of neonatal pigs
}

\author{
P J Williams, N Marten, V Wilson, J C Litten-Brown, A M Corson², L Clarke², \\ M E Symonds and A Mostyn \\ Institute of Clinical Research, Centre for Reproduction and Early Life, University Hospital, Nottingham NG7 2UH, UK, \\ ${ }^{1}$ School of Agriculture, Policy and Development, University of Reading, Reading RG6 6AR, UK and ${ }^{2}$ Faculty of \\ Natural Sciences, Imperial College London, Wye, Kent TN25 5AH, UK \\ Correspondence should be addressed to A Mostyn who is now at School of Nursing, University of Nottingham, Nottingham \\ NG7 2HA, UK; Email: alison.mostyn@nottingham.ac.uk
}

\begin{abstract}
Epidemiological studies suggest that low-birth weight infants show poor neonatal growth and increased susceptibility to metabolic syndrome, in particular, obesity and diabetes. Adipose tissue development is regulated by many genes, including members of the peroxisome proliferator-activated receptor (PPAR) and the fatty acid-binding protein (FABP) families. The aim of this study was to determine the influence of birth weight on key adipose and skeletal muscle tissue regulating genes. Piglets from 11 litters were ranked according to birth weight and 3 from each litter assigned to small, normal, or large-birth weight groups. Tissue samples were collected on day 7 or 14. Plasma metabolite concentrations and the expression of PPARG2, PPARA, FABP3, and FABP4 genes were determined in subcutaneous adipose tissue and skeletal muscle. Adipocyte number and area were determined histologically. Expression of FABP3 and 4 was significantly reduced in small and large, compared with normal, piglets in adipose tissue on day 7 and in skeletal muscle on day 14 . On day 7, PPARA and PPARG2 were significantly reduced in adipose tissue from small and large piglets. Adipose tissue from small piglets contained more adipocytes than normal or large piglets. Birth weight had no effect on adipose tissue and skeletal muscle lipid content. Low-birth weight is associated with tissue-specific and time-dependent effects on lipid-regulating genes as well as morphological changes in adipose tissue. It remains to be seen whether these developmental changes alter an individual's susceptibility to metabolic syndrome. Reproduction (2009) 138 609-617
\end{abstract}

\section{Introduction}

Human epidemiological studies have demonstrated that suboptimal conditions in utero, for example resulting in a low-birth weight offspring, are associated with development of metabolic syndrome in later life (Barker 1998). The molecular and pathological features of a number of the components of metabolic syndrome, including obesity and type-2 diabetes, have therefore been explored through a range of both small and large animal studies (Poore \& Fowden 2002, Gardner et al. 2005, Taylor et al. 2005). These studies have demonstrated that suboptimal conditions in utero, such as under- or overnutrition, which may lead to altered fetal growth, can 'reprogram' tissue-specific endocrine and physiological regulatory systems (Poore \& Fowden 2004a, Gardner et al. 2005, Erhuma et al. 2007). As a consequence, the offspring are at increased risk of developing obesity, and subsequently, diabetes via dysregulation of adipose tissue distribution, and impaired lipid metabolism. In the pig, low-birth weight is associated with catch-up growth and then increased fat mass, impaired glucose tolerance, and increased adrenal responsiveness to insulin at 1 year of age (Poore \& Fowden 2002, 2004a, 2004b, Marten et al. 2009).

These findings support human studies indicating that low-birth weight followed by catch-up growth is associated with increased risk of developing obesity, diabetes, and hypertension in later life (Eriksson et al. 2003a, 2003b, Min et al. 2007). The molecular mechanisms behind these pathologies, however, remain to be established. There is also evidence to suggest that offspring born to mothers who have experienced overfeeding in pregnancy are at risk from metabolic disease in later life, although these studies are currently limited to feeding pregnant rats abnormally high quantities of lipid during pregnancy (i.e. 5 (corn oil) versus 25\% (lard)) and the offspring are not heavier at 7 days of postnatal age (Khan et al. 2005, Taylor et al. 2005). 
Obesity is the most common risk factor for development of metabolic syndrome, which is characterized by insulin resistance leading to increased plasma triglyceride and non-esterified fatty acid (NEFA) concentrations (Frayn 2002, Grundy 2004, Zimmet et al. 2005). Although the molecular pathways that link obesity with such a wide spectrum of metabolic and cardiovascular disease are not well defined, recent studies have focussed on the role of adipose tissue in the development of metabolic syndrome (Ferroni et al. 2004, Moller \& Kaufman 2005) in which fatty acid binding protein (FABP) 4 may have a central role (Hotamisligil et al. 1996, Scheja et al. 1999, Uysal et al. 2000, Furuhashi et al. 2007, Ordovas 2007).

Adipose tissue differentiation is regulated by a number of transcription factors, with the nuclear receptor peroxisome proliferator-activated receptor (PPAR)G considered to be the master regulator of adipogenesis and is involved in the regulation of fatty acid uptake and storage (Rosen et al. 1999). There are two distinct isoforms of PPARG, with PPARG2 expression limited to adipose tissue where it is ten times more active than PPARG1 in ligand-independent transcriptional activation (Werman et al. 1997), and its induction occurs very early in pre-adipocyte differentiation (Saladin et al. 1999). PPARG2 induction is followed by the expression of multiple genes and proteins including FABP4 that are involved in intracellular fatty acid transportation, cell growth and differentiation, cellular signaling, gene transcription, and modulation of enzyme activity (Heuckeroth et al. 1987, Amri et al. 1991, Zimmerman \& Veerkamp 2002). The FABP with the widest tissue distribution is FABP3 (muscle FABP) that plays a critical role in the uptake and utilization of NEFA, in fuel selection and energy metabolism, and in adult pigs it is genetically linked to intramuscular fat content (Glatz et al. 1998, Binas et al. 1999, Gerbens et al. 2001, Luiken et al. 2003). Recent studies have suggested a more wide spread tissue distribution of FABPs (Gardan et al. 2007, $\mathrm{Li}$ et al. 2007) that may be linked to PPAR action (Motojima 2000, Tan et al. 2002).

We have previously shown that birth weight is one factor determining gene expression of uncoupling protein $(U C P) 2$ and 3 in adipose tissue of piglets (Mostyn et al. 2005). The reduction in UCP expression observed in small piglets may be mediated in part by differential regulation of PPARs and FAPBs gene expression, and ultimately may lead to a build up of fatty acids in of adipose tissue and cause lipotoxicity (Aubert et al. 1997, Schrauwen et al. 2001). The aim of the present study was therefore to investigate the influence of birth weight on expression of FABP3 and 4, PPARA and PPARG2 in adipose tissue and skeletal muscle during early neonatal development.

\section{Results}

\section{Gene expression}

FABP3

The abundance of FABP3 mRNA in adipose tissue was lower in both small and large compared with normal sized piglets on day 7 , but not day 14 , of postnatal age (Fig. 1a). In skeletal muscle, when compared with normal-sized piglets, gene expression of $F A B P 3$ was significantly reduced in both small and large offspring on day 14 , but not day 7 , of postnatal age when compared with normal offspring (Fig. 1b). An unexpected observation was that gene expression of the muscle specific $F A B P 3$ was higher in adipose tissue compared with skeletal muscle. A significant downregulation of FABP3 with age only occurred in skeletal muscle of small piglets.

\section{FABP4}

FABP4 mRNA abundance was lower in the adipose tissue of small and large compared with normal-sized offspring on day 7 only (Fig. 2a). In contrast, gene expression of $F A B P 4$ in skeletal muscle only differed with birth weight at day 14 , but not day 7 , when its expression
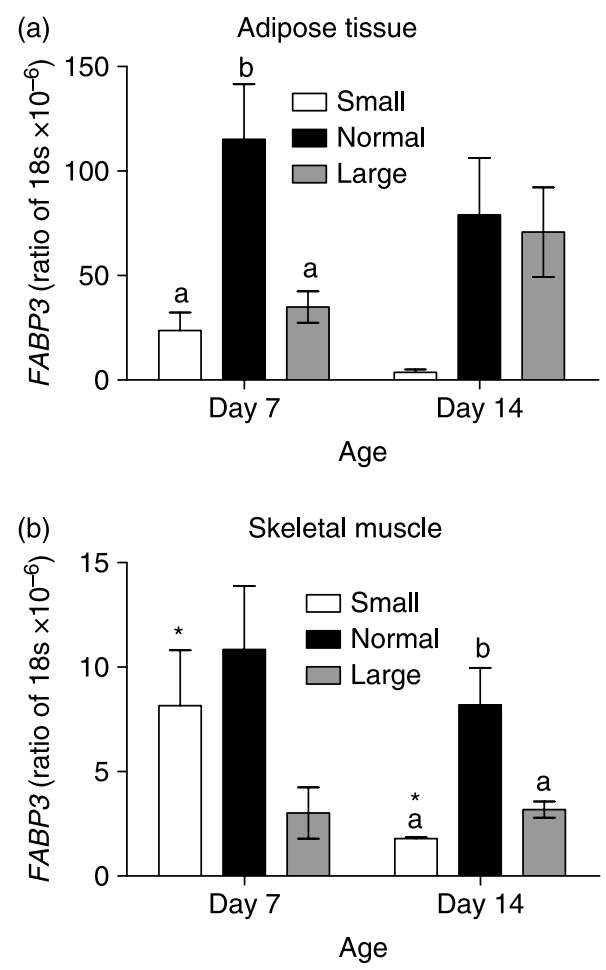

Figure 1 (a) Mean fatty acid-binding protein (FABP) 3 gene expression in subcutaneous adipose tissue on day 7 ( $n=5$ per group) and 14 ( $n=6$ per group) of postnatal age in small, normal, and large piglets. (b) Mean FABP3 gene expression in skeletal muscle on day $7(n=5$ per group) and $14(n=6$ per group) of postnatal age in small, normal, and large piglets. Values are means with their S.E.M. Significant differences $(P<0.05)$ between birth weight groups are represented by different superscripts, significant differences between postnatal ages are represented by an asterisk. 

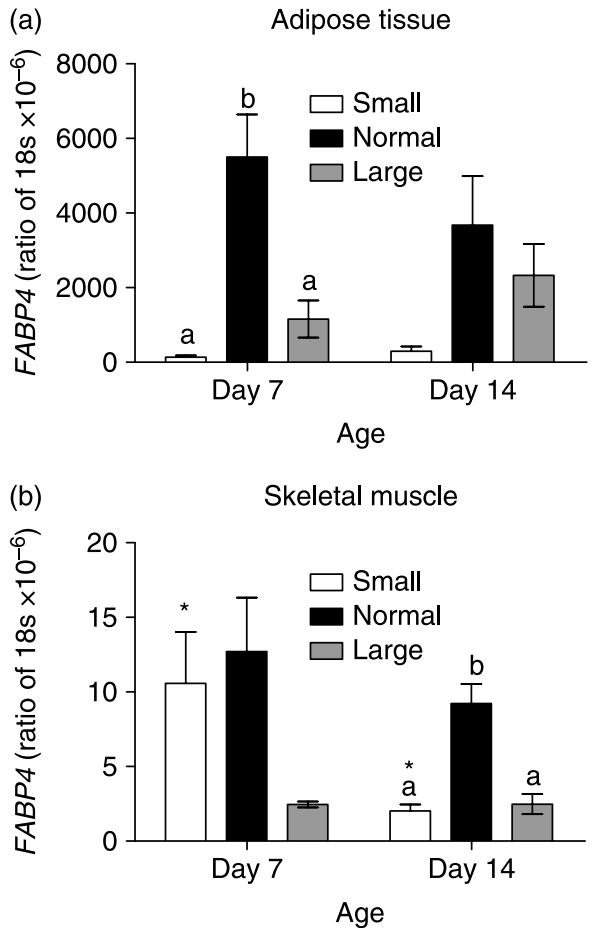

Figure 2 (a) Mean fatty acid-binding protein $(F A B P) 4$ gene expression in subcutaneous adipose tissue on day 7 ( $n=5$ per group) and 14 ( $n=6$ per group) of postnatal age in small, normal, and large piglets. (b) Mean FABP4 gene expression in skeletal muscle on day 7 ( $n=5$ per group) and 14 ( $n=6$ per group) of postnatal age in small, normal, and large piglets. Values are means with their S.E.M. Significant differences $(P<0.05)$ between birth weight groups are represented by different superscripts, significant differences between postnatal ages are represented by an asterisk.

in normal-sized offspring was greater compared with small and large piglets (Fig. 2b). There was a significant downregulation of FABP4 in skeletal muscle of small piglets between days 7 and 14 . The expression of FABP4 mRNA was greater in adipose tissue compared with skeletal muscle.

\section{PPARA and PPARG2}

As observed with FABP4, gene expression of PPARA and PPARG2 was lower in the adipose tissue of small and large size offspring on day 7 , but not day 14 , of postnatal life (Figs 3 and 4). There was a significant downregulation of PPARA mRNA abundance in adipose tissue of normal piglets between days 7 and 14. PPARA and PPARG2 were below the level of detection in all skeletal muscle samples.

\section{Tissue lipid content}

There were no differences in adipose or skeletal muscle tissue lipid concentrations between small, normal, or large piglets on day 7 or 14 (e.g. adipose tissue day 7 small, $102.5 \pm 55.4$; normal $98.1 \pm 21.5$ and large $93.9 \pm 15.7 \mathrm{mg} / \mathrm{g}$ ). There was, however, a positive relationship observed between the skeletal muscle lipid content and FABP4 and FABP3 in normal-sized piglets on day 14 (Table 1 ).

\section{Plasma metabolites}

We have previously shown that there were no differences in plasma metabolite concentrations between small, normal, or large piglets on days 7 or 14 (Mostyn et al. 2005). There was, however, a significant relationship between plasma NEFA concentrations and FABP4 gene expression in skeletal muscle on day 14 (Fig. 5). In this regard, small and large piglets exhibited a negative relationship whereas it was positive in normal-sized piglets. No significant relationships were found between the abundance of any gene examined and individual growth rates (fractional or absolute) in any birth weight group.

\section{Histological examination}

Adipocyte area was not statistically different between groups (small, 2843 \pm 231.1 ; normal, $3061 \pm 285.0$; large, $3362.5 \pm 466.5 \mu \mathrm{m}^{2}$ ), but this difference may be biologically important. Adipocyte number was significantly higher in the small compared to the normal and large groups (Fig. 6) on day 7 . There were significant relationships between adipocyte number and size and a number of the genes and metabolites of interest (Table 2). A negative relationship was observed in the small piglets only between adipocyte number and adipose tissue FABP3 expression on day 7. Adipocyte area was negatively related to birth weight and plasma NEFA on day 7 in the normal piglets only.

\section{Discussion}

Our study has demonstrated that birth weight has a substantial effect on the primary genes involved in adipocyte development and lipid metabolism in both

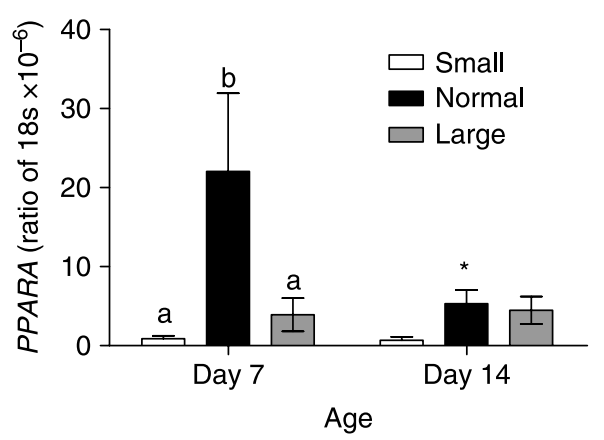

Figure 3 Mean peroxisome proliferator-activated receptor $(P P A R) A$ gene expression in subcutaneous adipose tissue on day 7 ( $n=5$ per group) and 14 ( $n=6$ per group) of postnatal age in small, normal, and large piglets. Values are means with their S.E.M. Significant differences $(P<0.05)$ between birth weight groups are represented by different superscripts, significant differences between postnatal ages are represented by an asterisk. 


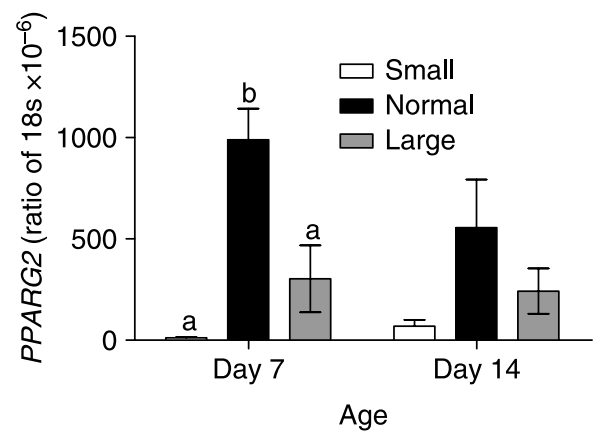

Figure 4 Mean peroxisome proliferator-activated receptor (PPAR) Ggene expression in subcutaneous adipose tissue on day 7 ( $n=5$ per group) and 14 ( $n=6$ per group) of postnatal age in small, normal, and large piglets. Values are means with their S.E.M. Significant differences $(P<0.05)$ between birth weight groups are represented by different superscripts.

adipose tissue and skeletal muscle during the neonatal period. Interestingly, in our porcine model, a lower or higher than normal birth weight was found to affect the gene expression of FABP3, FABP4, PPARA, and $P P A R G 2$, which are likely to be linked to changes in lipid metabolism, although we have not measured this directly in the current study (Binas et al. 1999, Norris et al. 2003, Boord et al. 2004, Martin et al. 2007). Further work should include assessment of whether the changes in mRNA expression are translated to protein.

\section{FABP3 and FABP4}

FABP3 is traditionally considered to be a 'muscle' FABP (and commonly called heart FABP) as confirmed by studies in adult pigs (Li et al. 2007). Our findings in the neonatal pig suggest, however, that the expression profile is very different in early life and is dependent, in part, on birth weight. More recently, the presence of FABP3 in subcutaneous adipose tissue and intramuscular adipocytes has been shown in adult pigs, supporting the proposal that FABP distribution is not tissue specific (Gardan et al. 2007). We have demonstrated that FABP3 is expressed in adipose tissue at quantities tenfold greater than in skeletal muscle and high abundance is attained soon after birth irrespective of body weight, in keeping with $\mathrm{Li}$ et al. (2007) who demonstrated that adult levels were achieved by day 7 of postnatal age. FABP3 in adipose tissue decreases with age in small piglets only which may represent a developmental difference in these animals.

Decreased gene expression of $F A B P 3$ and 4 in adipose tissue of small and large piglets on day 7 suggests that fatty acid metabolism is reset in these offspring. There were, however, no immediate differences in lipid content of adipose tissue or plasma NEFA or triglycerides between groups. Small piglets did, however, possess more adipocytes compared with their large siblings, although the extent to which this may determine later fat mass remains to be established (Spalding et al. 2008). It is possible that lower FABP3 could be a beneficial adaptation as both gene ablation or partial reduction in FABP3 protein is protective against the onset of symptoms of type-2 diabetes, at least in mice fed a very high fat diet (Binas et al. 1999, Shearer et al. 2005). Indeed, reduced gene expression of both FABP3 and 4 may actually be protective against the development of metabolic syndrome as a number of recent studies suggest FABP4 is central to its onset (Boord et al. 2004, Makowski \& Hotamisligil 2004, Maeda et al. 2005). A protective effect in this case seems unlikely, given the well-described $U$ - or J-shaped relationship between birth weight and obesity and metabolic syndrome (Martorell et al. 2001).

The differential relationships between plasma NEFA and FABP4 expression in muscle that was dependent on size at birth suggests altered integration between plasma lipids and tissue FABP4 in both small and large piglets. Coordination of FAPB4 and PPARG expression has previously been demonstrated (Tan et al. 2002), a relationship necessary to mediate the transcriptional activities of the PPAR ligand (for example NEFA) that is carried by the FABP. Despite this coordinated relationship, there were no differences in skeletal muscle triglyceride content between groups in the present study.

The unexpectedly high gene expression of FABP3 in adipose tissue of neonatal pigs may be due to its extensive growth and differentiation as subcutaneous fat mass increases by 10-20-fold after birth (Mitchell et al. 2001), requiring a significant influx of lipid. FABP3 is known to facilitate long-chain fatty acid uptake, oxidation, and esterification in myocytes (Binas \& Erol 2007). Currently, there is little information regarding the

Table 1 Influence of postnatal age and relative size of birth on the relationship between fatty acid-binding protein (FABP) and peroxisome proliferator-activated receptor (PPAR) gene expression in subcutaneous adipose tissue or skeletal muscle with plasma non-esterified fatty acid (NEFA) concentration or triacylglyceride (TAG) content.

\begin{tabular}{lllllccc}
\hline Age & Birth weight & Tissue & X-axis & Y-axis & $\boldsymbol{R}^{2}$ & Equation & $\boldsymbol{n}$ \\
\hline 7 & Large & SAT & PPARG2 & FABP4 SAT & 0.848 & $y=0.028 x+3.18$ & 5 \\
7 & Small & SAT & PPARG2 & NEFA & 0.989 & $y=0.023 x+0.90$ & 4 \\
7 & Large & SAT & FABP4 & TAG & 0.791 & $y=-0.016 x+1.29$ & 5 \\
14 & Normal & Muscle & FABP3 & Muscle TAG content & 0.78 & $y=0.03 x+1.3$ & 0.005 \\
14 & Normal & Muscle & FABP4 & Muscle TAG content & 0.733 & $y=0.28 x-0.98$ & 6 \\
14 & Normal & SAT & FABP4 & PPARG2 SAT & 0.764 & $y=15.8 x-25.7$ & 0.02 \\
\end{tabular}




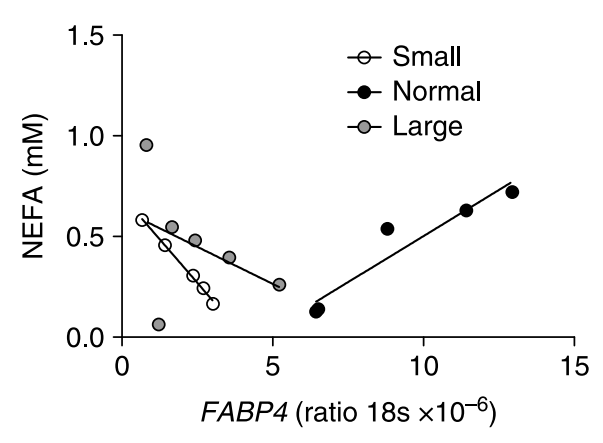

Figure 5 Relationship between plasma non-esterified fatty acid (NEFA) concentration and gene expression of FABP4 in skeletal muscle at 14 days of postnatal age. Small, $R^{2}=0.97(y=-0.17 x+0.7)$; normal, $R^{2}=0.91(y=0.09 x-0.41)$; large, $R^{2}=0.16(y=-0.07 x-0.63)$.

role of FABP3 in adipose tissue, but we hypothesize that NEFA metabolism has a central role during neonatal fat development. In contrast, changes in gene expression of $F A B P 3$ and FABP4 were not observed until day 14 in skeletal muscle when reduced expression was seen in all offspring that were not within the normal ranges of birth weight. The emergence of differences in FABP3 and 4 in skeletal muscle at an older age compared to adipose tissue may reflect the fact that carbohydrate, rather than lipid, metabolism in skeletal muscle (and liver) is crucial during the first week of life in the pig due to the lack of lipid reserves at birth (Mersmann 1974, Mitchell et al. 2001). In the first 14 days of life, adipose tissue in the pig becomes unilocular with a substantial accumulation of triglycerides (Mersmann 1974), changes requiring cooperation with FABPs as well as PPARG. It is very unlikely that the presence of FABP4 in skeletal muscle could be due to the accumulation of intramuscular adipocytes at this early stage of development.

\section{PPARG2 and $A$}

PPARG is considered as the master controller of adipogenesis, and a reduction in expression of PPARG2 in adipose tissue of the small and large piglets suggests delayed development. The histological data partly confirm this as the small but not the larger piglets have more adipocytes per visual field on day 7 (Fig. 6),

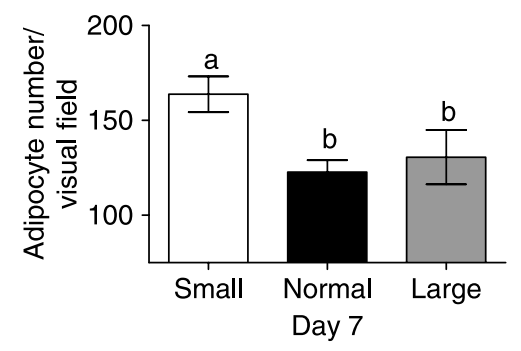

Figure 6 Mean adipocyte number in subcutaneous adipose tissue on day 7 ( $n=5$ per group) of postnatal age in small, normal, and large piglets. Values are means with their S.E.M. Significant differences $(P<0.05)$ between birth weight groups are represented by different superscripts. yet these are of a similar size to normal and large piglets and possess similar triglyceride concentrations. This suggests that triglyceride is not being taken into the adipocytes of the small piglets at the same rate as normal and large piglets. In addition, PPARG2 plays a role in controlling adipose tissue expandability and increasing the capacity for buffering toxic lipids in a mouse knockout model (Medina-Gomez et al. 2007). Under conditions of positive energy balance, these mice exhibited severe insulin resistance and other features of metabolic syndrome (Medina-Gomez et al. 2007). While extrapolation to the pig is limited, one may speculate that reduced PPARG2 on day 7 may cause an increase in reactive lipid species and a reduced ability to buffer excess lipid. Such an adaptation would be further exacerbated by the reduction in expression of UCP2 and 3 in adipose tissue of these offspring (Mostyn et al. 2005). Offspring born to rats fed a low-protein, high-carbohydrate diet in pregnancy have reduced in PPARG in adipose tissue (Burdge et al. 2004), which is accompanied with impaired insulin sensitivity. These findings are in accord with glucose intolerance in low-birth weight offspring at 12 months of age (Poore \& Fowden 2002). In the adult human, activation of PPARG by members of the thiazolidinedione (or glitazone) drug group sensitizes peripheral tissues to insulin by stimulating glucose and fatty acids uptake into adipocytes and increasing transcription of genes involved in insulin signaling. These functions may be impaired in both small and large offspring and fit in with epidemiological data indicating an increase risk of later metabolic disease in both small (Eriksson et al. 2003a, 2003b, Min et al. 2007) and large infants (Gillman et al. 2003, Leong et al. 2003, Danielzik et al. 2004).

PPARA has a well-documented role in hepatic lipid metabolism (Stienstra et al. 2007), but its role in adipose tissue and relationship to birth weight are less clear. Previous studies investigating the role of fetal programming in the female offspring of mice fed a high unsaturated fat diet during pregnancy have demonstrated increased PPARA protein in liver along with decreased hepatic triglyceride concentrations (Zhang et al. 2005). This is perceived as a potentially protective mechanism, although it should be noted that the high-fat diets adopted contain large quantities of saturated animal fats (Khan et al. 2005) and thus are not representative of the diet normally consumed by rodents. In the present study, the reduction in PPARA in low- and high-birth weight piglets on day 7 suggests that lipid oxidation is reduced. Despite tissue triglyceride being similar between groups, we have not assessed tissue lipids. PPARA is also a modulator of NEFA uptake into cells and upregulates the expression of key proteins that facilitate NEFA transport, although this is most pronounced in hepatocytes; however, clofibrate (a PPARA agonist) was found to upregulate fatty acid translocase and fatty acid transport protein in white adipose tissue of mice 
Table 2 Influence of size at birth on the relationship between subcutaneous adipocyte number or area and fatty acid-binding protein (FABP) gene expression or plasma non-esterified fatty acid (NEFA) concentration.

\begin{tabular}{llllll}
\hline Group & $\boldsymbol{X}$-axis & Y-axis & $\boldsymbol{R}^{\mathbf{2}}$ & Equation & $\boldsymbol{n}$ \\
\hline Small & Adipocyte number & FABP3 & $R^{2}=0.87$ & $y=-11.6 x+56.3$ & 4 \\
Normal & Adipocyte area & Body weight day 0 & $R^{2}=0.74$ & $y=-0.0003 x+2.3$ & 5 \\
Normal & Adipocyte area & NEFA day 7 & $R^{2}=0.97$ & $y=-0.001 x+5.7$ & 0.001 \\
& &
\end{tabular}

(Motojima et al. 1998). A reduction in lipid uptake into subcutaneous adipose tissue would be consistent with the reduced influence of PPARG2 on adipocyte maturation at this stage in the small and large piglets. The lack of PPARA mRNA expression in skeletal muscle may be related to the age of the piglets in this study. Evidence for the developmental ontogeny of PPARA in skeletal muscle of the pig is sparse; a small trial of two porcine breeds by Sundvold et al. demonstrated no expression of PPARA in muscle from 5-day-old pigs, with a slight increase up to 5 weeks and no further increase at 22-28 weeks (Sundvold \& Lien 2001). Sebert et al. (2005) demonstrated an increase in muscle PPARA expression in mini-pigs between 10 and 16 months; however, this increase was restricted to the overfed group. The undetectable level of PPARA in skeletal muscle may provide the pigs with a greater circulating source of lipid during the neonatal period. Sundvold et al. also demonstrated a genotype effect with differential expression of PPARA in two porcine breeds. In contrast to the present study, PPARA was undetectable in adipose tissue expression; this could be a genotype effect (Duroc and Landrace pigs were used by Sundvold et al. (2001)) or due to northern blotting being insufficiently sensitive to detect PPARA.

In conclusion, we have shown that both a low- and high-birth weight can impact the development and potential function of both adipose tissue and skeletal muscle during the neonatal period. Further studies are now needed to investigate how long these alterations in gene expression persist and what impact they may have on disease susceptibility particularly when followed by catch-up growth that often occurs in small offspring (Ibanez et al. 2008).

\section{Materials and Methods}

\section{Animals}

Eleven large white sows of similar body weight (day 109; 274 $\pm 5.2)$ and parity $(2.7 \pm 0.3)$ were entered into the study and were all fed a standard commercial diet through pregnancy. All sows were housed individually in a temperature-controlled barn $\left(24^{\circ} \mathrm{C} \pm 2\right)$ and gave birth normally at term. On the first day of life, piglets were ranked according to birth weight within each litter. Three animals from each litter were assigned to small $(n=11)$, normal $(n=11)$, or large $(n=11)$ groups and randomly designated for tissue sampling on either day 7 (small, normal, and large; $n=5$ per group) or day 14 (small, normal, and large; $n=6$ per group) of postnatal age. The birth weight ranges for the groups were small, $0.8-1.33 \mathrm{~kg}$; normal, $1.24-1.75 \mathrm{~kg}$; and large, $1.35-2.11 \mathrm{~kg}$. The numbers of male and female piglets were evenly distributed among the groups. On days $0,4,7$, and 14 of postnatal age, piglets were weighed. It should be noted that as this study was designed to reflect normal neonatal development, it would not have been possible to separate the piglets from their mothers or control-feeding times/volumes at this stage of development. All piglets from each litter, whether included in the study or not, remained with their mother for the duration of the experiment. On the assigned tissue sampling day, piglets were humanely killed with an overdose of barbiturate anaesthetic $(200 \mathrm{mg} / \mathrm{kg}$ pentobarbital sodium; Euthatal: RMB Animal Health, Dagenham, UK). At this time, a representative sample of s.c. adipose tissue (the predominant fat store in the neonatal pig) together with skeletal muscle (biceps femoris) was rapidly dissected, placed in liquid nitrogen, and stored at $-80^{\circ} \mathrm{C}$ until analyzed. All operative procedures and experimental protocols had the required Home Office approval as designated by the Animals (Scientific Procedures) Act (1986).

\section{Laboratory procedures}

\section{Preparation of $m R N A$}

Total RNA was extracted from 50 to $100 \mathrm{mg}$ of each tissue using Tri-reagent (Sigma). Following RNA extraction, $1 \mu \mathrm{g}$ of each sample was reverse transcribed in a $20 \mu \mathrm{l}$ reaction containing buffer $(250 \mathrm{mM}$ Tris-HCL, $40 \mathrm{mM} \mathrm{MgCl} 2,150 \mathrm{mM} \mathrm{KCl}$, and $5 \mathrm{mM}$ dithioerythritol; pH 8.5), $2 \mathrm{mM}$ deoxyribonucleotide triphosphates, $1 \times$ hexanucleotide mix, $10 \cup$ RNase inhibitor, and $10 \mathrm{U}$ RT (Roche Diagnostics) in a Touchgene Gradient thermocycler (Techne, Barloworld Scientific Ltd, Stone, UK). The conditions used to generate first-strand cDNA were $72{ }^{\circ} \mathrm{C}$ $(5 \mathrm{~min}), 4{ }^{\circ} \mathrm{C}(2 \mathrm{~min}), 25^{\circ} \mathrm{C}(5 \mathrm{~min}), 25^{\circ} \mathrm{C}(10 \mathrm{~min}), 42{ }^{\circ} \mathrm{C}$ $(60 \mathrm{~min})$, and $72^{\circ} \mathrm{C}(10 \mathrm{~min})$. To ensure that there was no contaminating genomic DNA control, reactions without RT were included. RNA concentration and quality were verified by gel electrophoresis and spectrophotometrically using a standard conversion factor of 1 absorbance unit at $260 \mathrm{~nm} / 40 \mathrm{mg} \mathrm{RNA} / \mathrm{ml}$. RNA concentration was adjusted by dilution with nuclease-free water (Ambion, Warrington, UK) before cDNA synthesis to a standard concentration of $1 \mu \mathrm{g} / \mathrm{ml}$. All cDNA samples were stored at $-20{ }^{\circ} \mathrm{C}$ until use.

\section{Standard curve generation}

Standards for FABP3, FABP4, PPARA, PPARG2, and for the housekeeping gene $18 \mathrm{~s}$ ribosomal RNA were made from cDNA obtained from a randomly selected normal animal using semiquantitative PCR. The method used oligonucleotide primers to FABP3, FABP4, PPARA, PPARG2, and 18s genes 
Table 3 Primer sequences and optimal PCR conditions used.

\begin{tabular}{|c|c|c|c|c|}
\hline Gene & Primer sequence & Product size (bp) & Annealing temp $\left({ }^{\circ} \mathrm{C}\right)$ & GenBank ID (source) \\
\hline FABP3 & $\begin{array}{l}\text { Forward 5'-GCACTTACGAGAAAGAGGCATGA-3' } \\
\text { Reverse 5'-GCTGAGTCCAGGAGTAGCCAATT-3' }\end{array}$ & 74 & 60 & AJ416019 (Sus scrofa) \\
\hline FABP4 & $\begin{array}{l}\text { Forward 5' } 5^{\prime} \text {-GGAAAGTCAAGAGCACCATAACCT-3' } \\
\text { Reverse } 5^{\prime} \text {-ATTCCACCACCAACTTATCATCTACTATTT-3' }\end{array}$ & 116 & 60 & AJ416020 (Sus scrofa) \\
\hline PPARA & $\begin{array}{l}\text { Forward 5'-CGGAGAACCATTCGGCTAAAGC-3' } \\
\text { Reverse } 5^{\prime} \text {-CGAGAGGCACTTGTGGAAACG-3' }\end{array}$ & 110 & 60 & DQ437887 (Sus scrofa) \\
\hline PPARG2 & $\begin{array}{l}\text { Forward 5'-GAGATCACAGAGTATGCCAA } \\
\text { Reverse 5'-CTTGGGCTCCATAAAGTCA }\end{array}$ & 180 & 58 & DQ437885 (Sus scrofa) \\
\hline $18 \mathrm{~s}$ & $\begin{array}{l}\text { Forward 5'-GATGCGGCGGCGTTATTCC-3' } \\
\text { Reverse 5'-CTCCTGGTGGTGCCCTTCC-3' }\end{array}$ & 125 & 60 & AB117609 (Sus scrofa) \\
\hline
\end{tabular}

FABP, fatty acid-binding protein; PPAR, peroxisome proliferator-activated receptor.

generating specific intron-spanning products (see Table 3). The PCR program comprised an initial denaturation stage $\left(95^{\circ} \mathrm{C}, 15 \mathrm{~min}\right)$, amplification (stage I, $94^{\circ} \mathrm{C}(30 \mathrm{~s})$; stage II, annealing $\left(60{ }^{\circ} \mathrm{C}, 30 \mathrm{~s}\right)$; stage III, $72{ }^{\circ} \mathrm{C}(1 \mathrm{~min})$, and final extension $\left(72{ }^{\circ} \mathrm{C}, 7 \mathrm{~min} ; 8^{\circ} \mathrm{C}\right.$ 'hold'). The PCR mixture (final volume $20 \mu \mathrm{l}$ ) contained $7 \mu \mathrm{l}$ nuclease-free water (Ambion), $10 \mu \mathrm{l}$ thermo-start PCR master mix (50 $\mu$ l contains $1.25 \mathrm{U}$ Thermo-Start DNA polymerase, $1 \times$ thermo-start reaction buffer, $1.5 \mathrm{mM} \mathrm{MgCl}_{2}$, and $0.2 \mathrm{mM}$ each of denatured adenotriphosphate, denatured $2^{\prime}$-deoxycytidine $5^{\prime}$-triphosphate, denatured $2^{\prime}$-deoxyguanosine $5^{\prime}$-triphosphate, and denatured 2'-deoxythymidine $5^{\prime}$-triphosphate (ABgene, Epsom, UK)), $1 \mu$ l forward primer, $1 \mu$ l reverse primer, and $1 \mu \mathrm{l}$ RT (cDNA) product. The annealing temperature and cycle number of all primers were optimized and used in their linear range (Table 3). Agarose gel electrophoresis (2.0-2.5\%) and ethidium bromide staining confirmed the presence of both the product and $18 \mathrm{~s}$ at the expected sizes. All procedures were performed with appropriate negative and positive controls as well as a range of molecular weight markers (MBI Fermentas, York, UK).

The resultant PCR product was extracted (QIAquick gel extraction kit, Qiagen, cat no. 28704), sequenced, and results cross-referenced against the GenBank website to determine specificity of the target gene. After confirmation that the product was specific to the target gene, extracted PCR products were resuspended in nuclease-free water and a 10 -fold serial dilution performed. Standards were stored at $-20{ }^{\circ} \mathrm{C}$ until use in quantitative PCR.

\section{Quantitative (real-time) PCR}

Quantitative PCR was used to examine the expression of FABP3, FABP4, PPARA, PPARG2, and 18s (see Table 3). PCRs, set up in duplicate, were carried out in $20 \mu \mathrm{l}$ volumes consisting of $1 \times$ SYBR PCR mastermix (with ROX passive reference dye; Qiagen), $500 \mathrm{nM}$ forward primer, $500 \mathrm{nM}$ reverse primer, and $7 \mu \mathrm{l}$ nuclease-free water. Real-time PCR was performed in a Techne Quantica 14 real-time thermocycler (Techne, Barloworld Scientific Ltd) on all samples at $95^{\circ} \mathrm{C}$ (15 min) followed by 45 cycles of $95^{\circ} \mathrm{C}(15 \mathrm{~s})$, annealing temperature (see Table 3; $25 \mathrm{~s}$ ), $72{ }^{\circ} \mathrm{C}$ (25 s). Three negative control reactions were carried out with each set of samples analyzed: 1) no RNA template but RT and polymerase provided; 2) RNA and polymerase provided but no RT; and 3) RNA and RT provided but no polymerase. mRNA abundance was worked out as a ratio of concentration to the housekeeping gene, 18s. Absolute values for concentration were determined by the use of the standard curve.

\section{Histological analysis}

Frozen adipose tissue blocks from day 7 animals were cut to $5 \mu \mathrm{m}$ sections using a manual sledge microtome in a cryostat and the sections were stained with hematoxylin and eosin. Slides were viewed at 200 times magnification; three randomly selected visual fields were captured and adipocyte number and area $\left(\mu \mathrm{m}^{2}\right)$ were assessed using Volocity software (Improvision, Coventry, UK). The assessor was blinded to study group.

\section{Tissue lipid content}

Adipose tissue and skeletal muscle lipid content were assessed using the Folch assay (Folch et al. 1957) followed by colorimetric analysis for triglyceride content using a commercially available kit (Randox, Crumlin, Northern Ireland). Briefly, $500 \mathrm{mg}$ of tissue were homogenized in chloroform/ methanol $(1 / 1)$ to a final volume $20 \times$ the tissue sample. The homogenate was agitated for 15-20 min at room temperature then filtered to recover the liquid phase. The solvent was washed with 0.2 volumes of $0.9 \% \mathrm{NaCl}$ solution and vortexed for a few seconds. The resulting mixture was centrifuged at $700 \mathrm{~g}$ for $10 \mathrm{~min}$ to separate the two phases and the upper phase was discarded. The lower chloroform phase was subjected to triglyceride analysis.

\section{Plasma metabolites}

Plasma concentrations of NEFA were assessed using commercially available kits as described previously (Mostyn et al. 2005).

\section{Statistical analysis}

Results for real-time PCR are expressed as arbitrary units as a ratio of concentration of gene of interest/18s. Tests of normality as determined by the Kolmogorov-Smirnov test revealed that the data were parametric, thus statistically significant differences between all groups were determined by one-way ANOVA with post hoc individual paired comparisons used to determine differences between individual groups as appropriate. Correlations were tested using Pearson's test for 
parametric data; relationships between the genes measured, plasma metabolites and histological results were investigated. Results from the Pearson analysis were reported by group and sampling age. Statistical analysis was carried out using SPSS version 14 software (SPSS Inc., Chicago, IL, USA).

\section{Declaration of interest}

The authors declare that there is no conflict of interest that could be perceived as prejudicing the impartiality of the research reported.

\section{Funding}

This work was supported by Biotechnology and Biological Sciences Research Council Grant (S15331), the European Union Sixth Framework Programme for Research and Technical Development of the European Community - The Early Nutrition Programming Project (FOOD-CT-2005-007036) a University of Nottingham New Researchers grant and Institute of Clinical Research project grant.

\section{Acknowledgements}

The authors would like to acknowledge the experimental assistance of Mrs Katharine S Perkins.

\section{References}

Amri EZ, Bertrand B, Ailhaud G \& Grimaldi P 1991 Regulation of adipose cell differentiation. I. Fatty acids are inducers of the aP2 gene expression. Journal of Lipid Research 32 1449-1456.

Aubert J, Champigny O, Saint-Marc P, Negrel R, Collins S, Riquier D \& Ailhaud G 1997 Up-regulation of UCP-2 gene expression by PPAR agonists in preadipose and adipose cells. Biochemical and Biophysical Research Communications 238 601-611.

Barker DJP 1998 Mothers, Babies and Health in Later Life, Edinburgh: Churchill Livingstone.

Binas B \& Erol E 2007 FABPs as determinants of myocellular and hepatic fuel metabolism. Molecular and Cellular Biochemistry 299 75-84.

Binas B, Danneberg H, McWhir J, Mullins L \& Clark AJ 1999 Requirement for the heart-type fatty acid binding protein in cardiac fatty acid utilization. FASEB Journal 13 805-812.

Boord JB, Maeda K, Makowski L, Babaev VR, Fazio S, Linton MF \& Hotamisligil GS 2004 Combined adipocyte-macrophage fatty acidbinding protein deficiency improves metabolism, atherosclerosis, and survival in apolipoprotein E-deficient mice. Circulation 110 1492-1498.

Burdge GC, Phillips ES, Dunn RL, Jackson AA \& Lillycrop KA 2004 Effect of reduced maternal protein consumption during pregnancy in the rat on plasma lipid concentrations and expression of peroxisomal proliferatoractivated receptors in the liver and adipose tissue of the offspring. Nutrition Research 24 639-646.

Danielzik S, Czerwinski-Mast M, Langnase K, Dilba B \& Muller MJ 2004 Parental overweight, socioeconomic status and high birth weight are the major determinants of overweight and obesity in 5-7 y-old children: baseline data of the Kiel Obesity Prevention Study (KOPS). International Journal of Obesity and Related Metabolic Disorders 28 1494-1502.

Erhuma A, Salter AM, Sculley DV, Langley-Evans SC \& Bennett AJ 2007 Prenatal exposure to a low-protein diet programs disordered regulation of lipid metabolism in the aging rat. American Journal of Physiology 292 E1702-E1714.

Eriksson JG, Osmond C, Forsen TJ \& Barker DJP 2003a Pathways of infant and childhood growth that lead to type 2 diabetes. Diabetes Care $\mathbf{2 6}$ 3006-3010.
Eriksson JG, Forsen T, Tuomilehto J, Osmond C \& Barker DJP 2003b Early adiposity rebound in childhood and risk of type 2 diabetes in adult life. Diabetologia 46 190-194.

Ferroni P, Basili S, Falco A \& Davi G 2004 Inflammation, insulin resistance, and obesity. Current Atherosclerosis Reports 6 424-431.

Folch J, Lees M \& Stanley GHS 1957 A simple method for the isolation and purification of total lipids from animal tissues. Journal of Biological Chemistry 226 497-509.

Frayn KN 2002 Adipose tissue as a buffer for daily lipid flux. Diabetologia 45 1201-1210.

Furuhashi M, Tuncman G, Gorgun CZ, Makowski L, Atsumi G, Vaillancourt E, Kono K, Babaev VR, Fazio S, Linton MF et al. 2007 Treatment of diabetes and atherosclerosis by inhibiting fatty-acid-binding protein aP2. Nature 447 959-965.

Gardan D, Louveau I \& Gondret F 2007 Adipocyte- and heart-type fatty acid binding proteins are both expressed in subcutaneous and intramuscular porcine (Sus scrofa) adipocytes. Comparative Biochemistry and Physiology. Part B. Biochemistry and Molecular Biology 148 14-19.

Gardner DS, Tingey K, Van Bon BWM, Ozanne SE, Wilson V, Dandrea J, Keisler DH, Stephenson T \& Symonds ME 2005 Programming of glucoseinsulin metabolism in adult sheep after maternal undernutrition. American Journal of Physiology 289 R947-R954.

Gerbens F, Verburg FJ, Van Moerkerk HT, Engel B, Buist W, Veerkamp JH \& te Pas MF 2001 Associations of heart and adipocyte fatty acid-binding protein gene expression with intramuscular fat content in pigs. Journal of Animal Science 79 347-354.

Gillman MW, Rifas-Shiman S, Berkey CS, Field AE \& Colditz GA 2003 Maternal gestational diabetes, birth weight, and adolescent obesity. Pediatrics 111 e221-e226.

Glatz JF, Van Breda E \& Van der Vusse GJ 1998 Intracellular transport of fatty acids in muscle. Role of cytoplasmic fatty acid-binding protein. Advances in Experimental Medicine and Biology 441 207-218.

Grundy SM 2004 Obesity, metabolic syndrome, and cardiovascular disease. Journal of Clinical Endocrinology and Metabolism 89 2595-2600.

Heuckeroth RO, Birkenmeier EH, Levin MS \& Gordon JI 1987 Analysis of the tissue-specific expression, developmental regulation, and linkage relationships of a rodent gene encoding heart fatty acid binding protein. Journal of Biological Chemistry 262 9709-9717.

Hotamisligil GS, Johnson RS, Distel RJ, Ellis R, Papaioannou VE \& Spiegelman BM 1996 Uncoupling of obesity from insulin resistance through a targeted mutation in aP2, the adipocyte fatty acid binding protein. Science 274 1377-1379.

Ibanez L, Suarez L, Lopez-Bermejo A, Diaz M, Valls C \& de Zegher F 2008 Early development of visceral fat excess after spontaneous catch-up growth in children with low birth weight. Journal of Clinical Endocrinology and Metabolism 93 925-928.

Khan IY, Dekou V, Douglas G, Jensen R, Hanson MA, Poston L \& Taylor PD 2005 A high-fat diet during rat pregnancy or suckling induces cardiovascular dysfunction in adult offspring. American Journal of Physiology 288 R127-R133.

Leong NM, Mignone LI, Newcomb PA, Titus-Ernstoff L, Baron JA, Trentham-Dietz A, Stampfer MJ, Willett WC \& Egan KM 2003 Early life risk factors in cancer: the relation of birth weight to adult obesity. International Journal of Cancer 103 789-791.

Li B, Zerby HN \& Lee K 2007 Heart fatty acid binding protein is upregulated during porcine adipocyte development. Journal of Animal Science $\mathbf{8 5}$ 1651-1659.

Luiken JJ, Koonen DP, Coumans WA, Pelsers MM, Binas B, Bonen A \& Glatz JF 2003 Long-chain fatty acid uptake by skeletal muscle is impaired in homozygous, but not heterozygous, heart-type-FABP null mice. Lipids 38 491-496.

Maeda K, Cao H, Kono K, Gorgun CZ, Furuhashi M, Uysal KT, Cao Q, Atsumi G, Malone H, Krishnan B et al. 2005 Adipocyte/macrophage fatty acid binding proteins control integrated metabolic responses in obesity and diabetes. Cell Metabolism 1 107-119.

Makowski L \& Hotamisligil GS 2004 Fatty acid binding proteins- the evolutionary crossroads if inflammatory and metabolic responses. Journal of Nutrition 134 2464S-2468S. 
Marten N, Sebert S, Poore KR, Fowden AL, Symonds ME \& Mostyn A 2006 The influence of piglet birth weight on peroxisome proliferator activated receptor $\alpha$ (PPAR $\alpha)$ expression in skeletal muscle, Proceedings of the Neonatal Society, 2006 Widdowson (Autumn) meeting, Cambridge, UK.

Martin PGP, Guillou H, Lasserre F, Déjean S, Lan A, Pascussi J-M, SanCristobal M, Legrand P, Besse P \& Pineau T 2007 Novel aspects of PPARa-mediated regulation of lipid and xenobiotic metabolism revealed through a nutrigenomic study. Hepatology 45 767-777.

Martorell R, Stein AD \& Schroeder DG 2001 Early nutrition and later adiposity. Journal of Nutrition 131 874S-880S.

Medina-Gomez G, Gray SL, Yetukuri L, Shimomura K, Virtue S, Campbell M, Curtis RK, Jimenez-Linan M, Blount M, Yeo GSH et al. 2007 PPAR $\gamma 2$ prevents lipotoxicity by controlling adipose tissue expandability and peripheral lipid metabolism. PLoS Genetics 3 e64.

Mersmann HJ 1974 Metabolic patterns in the neonatal swine. Journal of Animal Science 38 1022-1030.

Min JW, Kong KA, Park BH, Hong JH, Park EA, Cho SJ, Ha E-H \& Park H 2007 Effect of postnatal catch-up growth on blood pressure in children at 3 years of age. Journal of Human Hypertension 21 868-874.

Mitchell AD, Scholz AM \& Mersmann HJ 2001 Growth and body composition. In Biology of the Domestic Pig, pp 225-308. Eds WG Pond \& HJ Mersmann. Cornell: Cornell University Press.

Moller DE \& Kaufman KD 2005 Metabolic syndrome: a clinical and molecular perspective. Annual Review of Medicine 56 45-62.

Mostyn A, Litten JC, Perkins KS, Euden PJ, Corson AM, Symonds ME \& Clarke L 2005 Influence of size at birth on the endocrine profiles and expression of uncoupling proteins in subcutaneous adipose tissue, lung and muscle of neonatal pigs. American Journal of Physiology $\mathbf{2 8 8}$ R1536-R1542.

Motojima K 2000 Differential effects of PPARalpha activators on induction of ectopic expression of tissue-specific fatty acid binding protein genes in the mouse liver. International Journal of Biochemistry and Cell Biology 32 1085-1092.

Motojima K, Passilly P, Peters JM, Gonzalez FJ \& Latruffe N 1998 Expression of putative fatty acid transporter genes are regulated by peroxisome proliferator-activated receptor $\alpha$ and $\gamma$ activators in a tissueand inducer-specific manner. Journal of Biological Chemistry 273 16710-16714.

Norris AW, Chen L, Fisher SJ, Szanto I, Ristow M, Jozsi AC, Hirshman MF, Rosen ED, Goodyear LJ, Gonzalez FJ et al. 2003 Muscle-specific PPAR $\gamma$ deficient mice develop increased adiposity and insulin resistance but respond to thiazolidinediones. Journal of Clinical Investigation 112 608-618.

Ordovas JM 2007 Identification of a functional polymorphism at the adipose fatty acid binding protein gene (FABP4) and demonstration of its association with cardiovascular disease: a path to follow. Nutrition Reviews 65 130-134.

Poore KR \& Fowden AL 2002 The effect of birth weight on glucose tolerance in pigs at 3 and 12 months of age. Diabetologia 45 1247-1254.

Poore KR \& Fowden AL 2004a Insulin sensitivity in juvenile and adult Large White pigs of low and high birthweight. Diabetologia 47 340-348.

Poore KR \& Fowden AL 2004b The effects of birth weight and postnatal growth patterns on fat depth and plasma leptin concentrations in juvenile and adult pigs. Journal of Physiology 558 295-304.

Rosen ED, Sarraf P, Troy AE, Bradwin G, Moore K, Milstone DS, Spiegelman BM \& Mortensen RM 1999 PPAR $\gamma$ is required for the differentiation of adipose tissue in vivo and in vitro. Molecular Cell $\mathbf{4}$ 611-617.

Saladin R, Fajas L, Dana S, Halvorsen Y-D, Auwerx J \& Briggs M 1999 Differential regulation of peroxisome proliferator activated receptorg1 (PPAR $\gamma 1$ ) and PPAR $\gamma 2$ messenger RNA expression in the early stages of adipogenesis. Cell Growth and Differentiation 10 43-48.
Scheja L, Makowski L, Uysal KT, Wiesbrock SM, Shimshek DR, Meyers DS, Morgan M, Parker RA \& Hotamisligil GS 1999 Altered insulin secretion associated with reduced lipolytic efficiency in $\mathrm{aP}^{-/-}$mice. Diabetes 48 1987-1994.

Schrauwen P, Saris WHM \& Hesselink MKC 2001 An alternative function for human uncoupling protein 3: protection of mitochondria against accumulation of nonesterified fatty acids inside the mitochondrial matrix. FASEB Journal 15 2497-2502.

Sebert SP, Lecannu G, Kozlowski F, Siliart B, Bard JM, Krempf M \& Champ MMJ 2005 Childhood obesity and insulin resistance in a Yucatan mini-piglet model: putative roles of IGF-1 and muscle PPARs in adipose tissue activity and development. International Journal of Obesity $\mathbf{2 9}$ 324-333.

Shearer J, Fueger PT, Bracy DP, Wasserman DH \& Rottman JN 2005 Partial gene deletion of heart-type fatty acid-binding protein limits the severity of dietary-induced insulin resistance. Diabetes 54 3133-3139.

Spalding KL, Arner E, Westermark PO, Bernard S, Buchholz BA, Bergmann O, Blomqvist L, Hoffstedt J, Naslund E, Britton T et al. 2008 Dynamics of fat cell turnover in humans. Nature 453 783-787.

Stienstra R, Mandard S, Patsouris D, Maass C, Kersten S \& Muller M 2007 Peroxisome proliferator-activated receptor $\alpha$ protects against obesityinduced hepatic inflammation. Endocrinology 148 2753-2763.

Sundvold H \& Lien S 2001 Identification of a novel peroxisome proliferatoractivated receptor $(\mathrm{PPAR}) \gamma$ promoter in mand and transactivation by the nuclear receptor ROR $\alpha$. Biochemical and Biophysical Research Communications 287 383-390.

Sundvold H, Grindflek E \& Lien S 2001 Tissue distribution of porcine peroxisome proliferator-activated receptor $(\alpha)$ : detection of an alternatively spliced mRNA. Gene 273 105-113.

Tan NS, Shaw NS, Vinckenbosch N, Liu P, Yasmin R, Desvergne B, Wahli W \& Noy N 2002 Selective cooperation between fatty acid binding proteins and peroxisome proliferator-activated receptors in regulating transcription. Molecular and Cellular Biology 22 5114-5127.

Taylor PD, McConnell J, Khan IY, Holemans K, Lawrence KM, AsareAnane H, Persaud SJ, Jones PM, Petrie L, Hanson MA et al. 2005 Impaired glucose homeostasis and mitochondrial abnormalities in offspring of rats fed a fat-rich diet in pregnancy. American Journal of Physiology 288 R134-R139.

Uysal KT, Scheja L, Wiesbrock SM, Bonner-Weir S \& Hotamisligil GS 2000 Improved glucose and lipid metabolism in genetically obese mice lacking aP2. Endocrinology 141 3388-3396.

Werman A, Hollenberg A, Solanes G, Bjorbak C, Vidal-Puig AJ \& Flier JS 1997 Ligand-independent activation domain in the $\mathrm{N}$ terminus of peroxisome proliferator-activated receptor $\gamma(\operatorname{PPAR} \gamma)$. Differential activity of PPAR $\gamma 1$ and -2 isoforms and influence of insulin. Journal of Biological Chemistry 272 20230-20235.

Zhang J, Wang C, Terroni PL, Cagampang FRA, Hanson M \& Byrne CD 2005 High-unsaturated-fat, high-protein, and low-carbohydrate diet during pregnancy and lactation modulates hepatic lipid metabolism in female adult offspring. American Journal of Physiology 288 R112-R118.

Zimmerman AW \& Veerkamp JH 2002 New insights into the structure and function of fatty acid-binding proteins. Cellular and Molecular Life Sciences 59 1096-1116.

Zimmet P, Alberti G \& Shaw J 2005 A new IDF worldwide definition of the metabolic syndrome: the rationale and the results. Diabetes Voice $\mathbf{5 0}$ $31-33$.

Received 23 October 2008

First decision 4 December 2008

Revised manuscript received 15 May 2009

Accepted 5 June 2009 